\title{
Streamflow of 2013 - Water Year Summary
}

\author{
U.S. Geological Survey
}

Reston, Virginia

January 2014

- Introduction

- National Overview

- Regional Patterns

- Seasonal Characteristics

- High and Low Flows

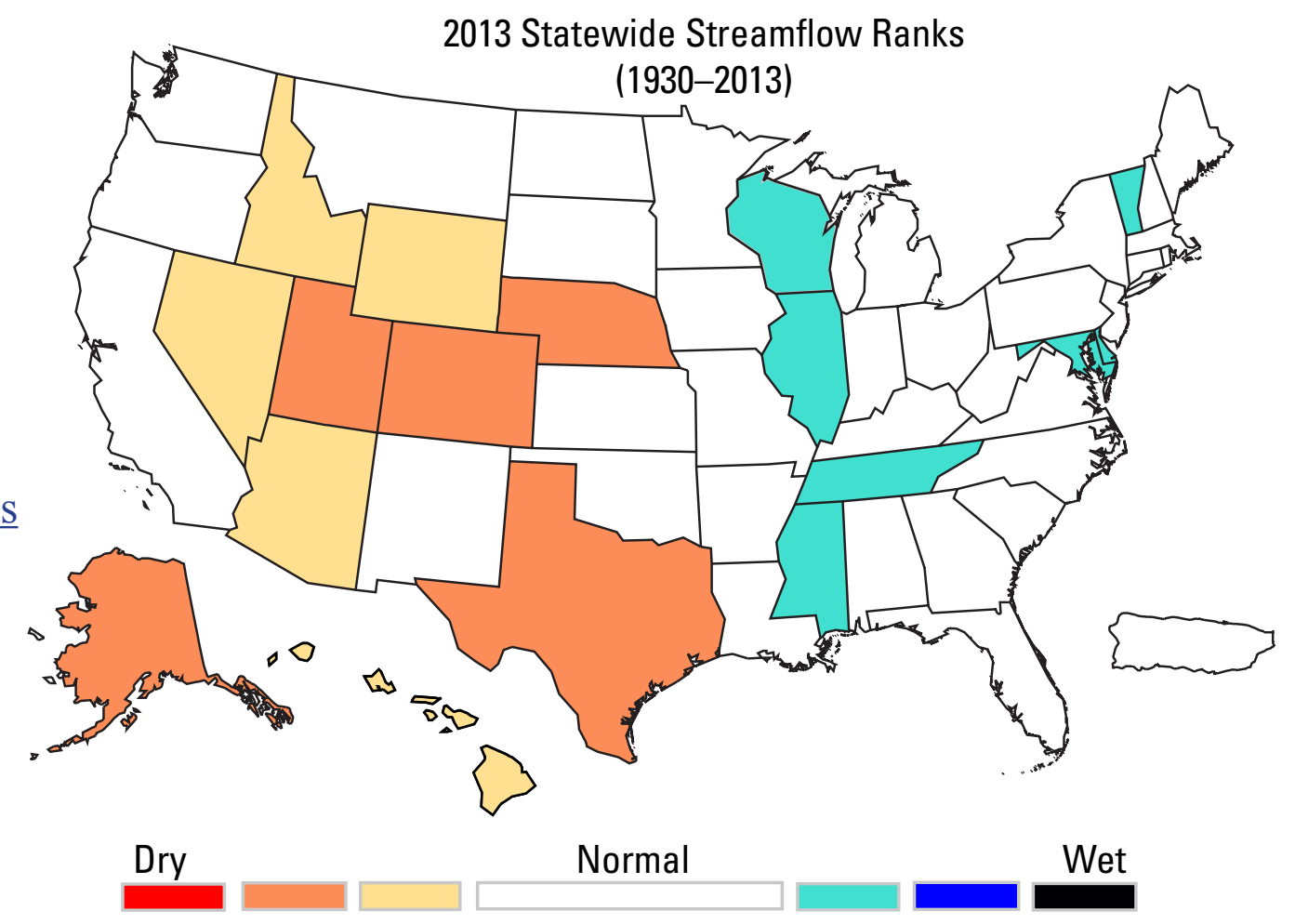

\section{Introduction}

The maps and graphs in this summary describe streamflow conditions for water year 2013 (October 1, 2012, to September 30, 2013) in the context of the 84-year period from 1930 through 2013, unless otherwise noted. The illustrations are based on observed data from the U.S. Geological Survey's (USGS) National Water Information System (http://water.usgs.gov/nwis/). The period 1930-2013 was used because, prior to 1930, the number of streamgages was too small to provide representative data for computing statistics for most regions of the country.

In the summary, reference is made to the term "runoff," which is the depth to which a river basin, State, or other geographic area would be covered with water if all the streamflow within the area during a specified time period was uniformly distributed upon it. Runoff quantifies the magnitude of water flowing through the Nation's rivers and streams in measurement units that can be compared from one area to another.

Each of the maps and graphs below can be expanded to a larger view by clicking on the image. In all the graphics, a rank of 1 indicates the highest flow of all years analyzed. 


\section{National Overview}

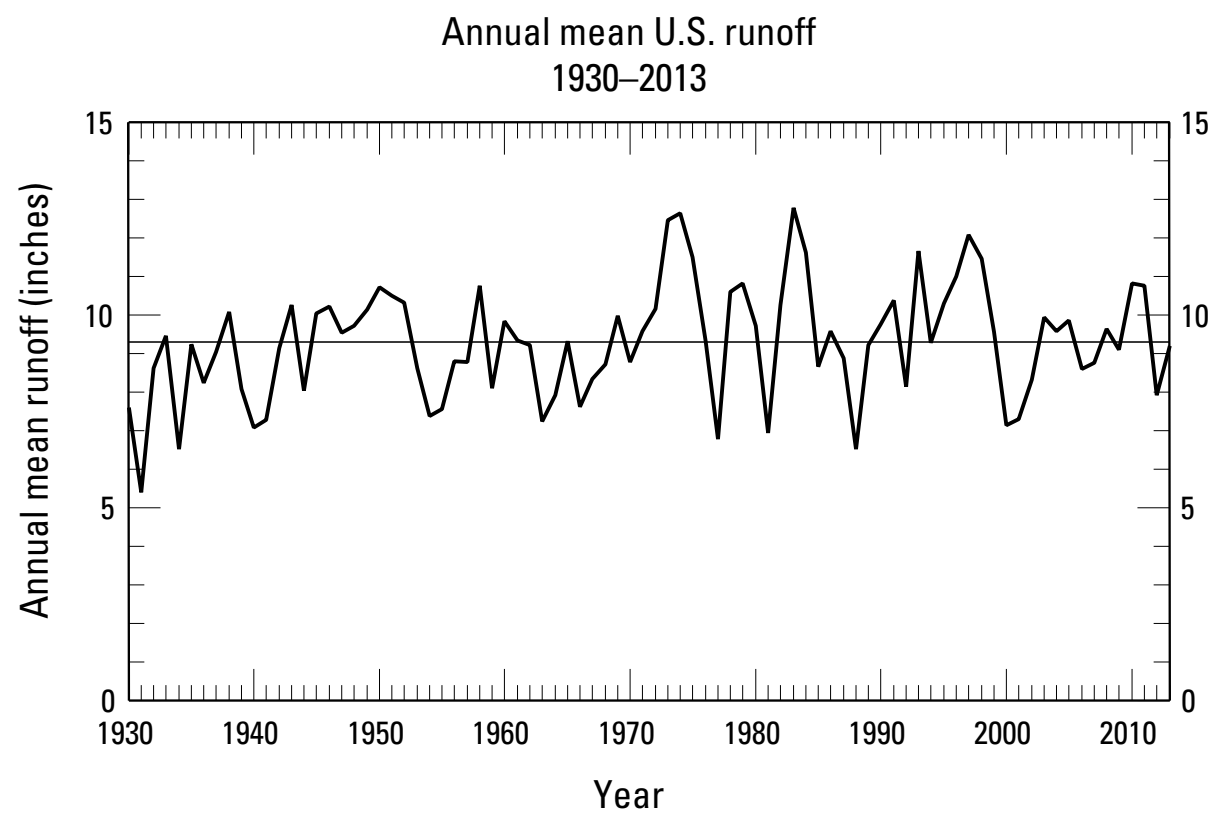

Average runoff in the Nation's rivers and streams during water year 2013 (9.21 inches) was very close to the long-term annual mean for the United States (9.30 inches). Nationwide, 2013 streamflow ranked 48th out of the 84 years in the period 1930-2013. Note that in previous water-year summaries (prior to 2011) the median runoff, not the average runoff, was compared among time periods.
2013 Statewide streamflow ranks

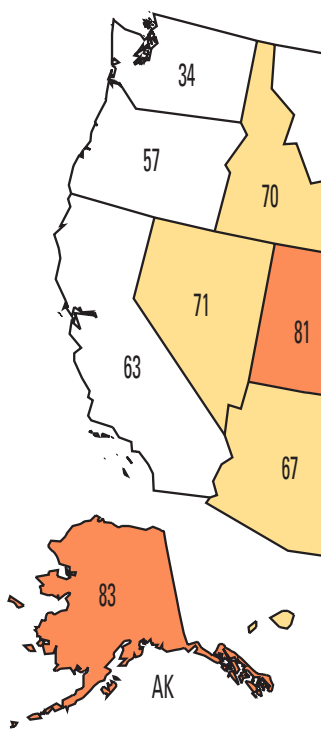

1930-2013

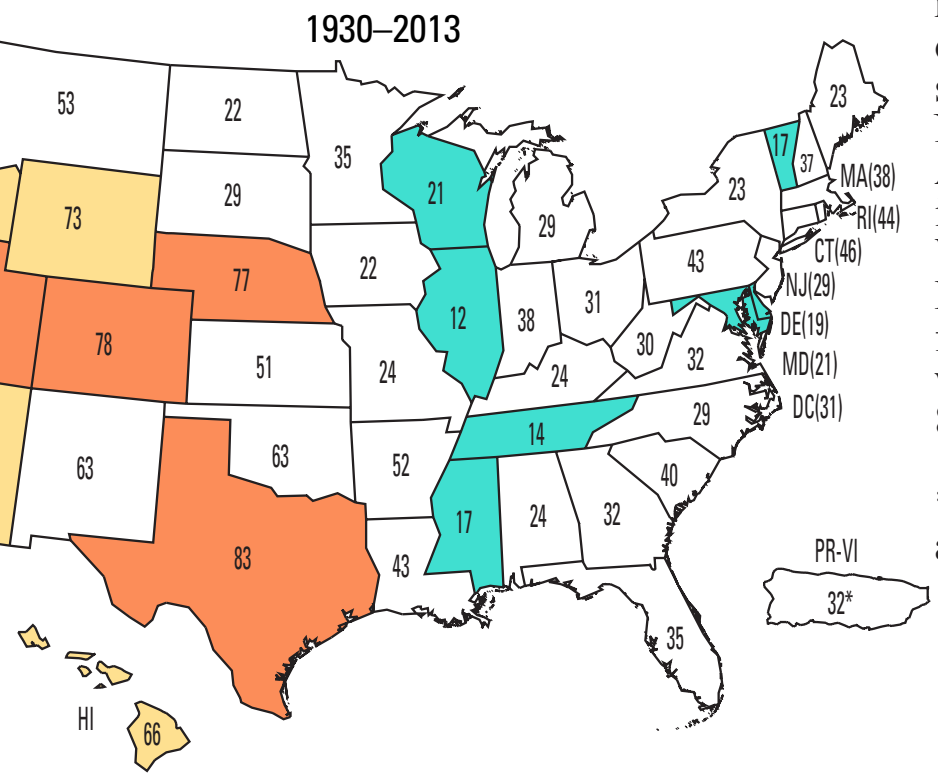

\section{Explanation - Rank}

\begin{tabular}{|c|c|c|c|c|c|c|}
\hline 84 & $77-83$ & $64-76$ & $22-63$ & $9-21$ & $2-8$ & 1 \\
\hline Lowest & $\begin{array}{c}\text { Much } \\
\text { below } \\
\text { normal }\end{array}$ & $\begin{array}{c}\text { Below } \\
\text { normal }\end{array}$ & Normal & $\begin{array}{c}\text { Above } \\
\text { normal }\end{array}$ & $\begin{array}{c}\text { Much } \\
\text { above } \\
\text { normal }\end{array}$ & Highest \\
\hline
\end{tabular}

Much-below-normal streamflow was reported in Texas, Alaska, Utah, Colorado, and Nebraska. Below-normal streamflow occurred in Wyoming, Nevada, Idaho, Arizona, and Hawaii. Above-normal streamflow occurred in Illinois, Tennessee, Mississippi, Wisconsin, Vermont, Delaware, and Maryland. Most States had streamflow in the normal range. Nationwide, streamflow ranked 48th out of 84 years.

* For Puerto Rico, 70 years of available data were used. 


\section{Regional Patterns}

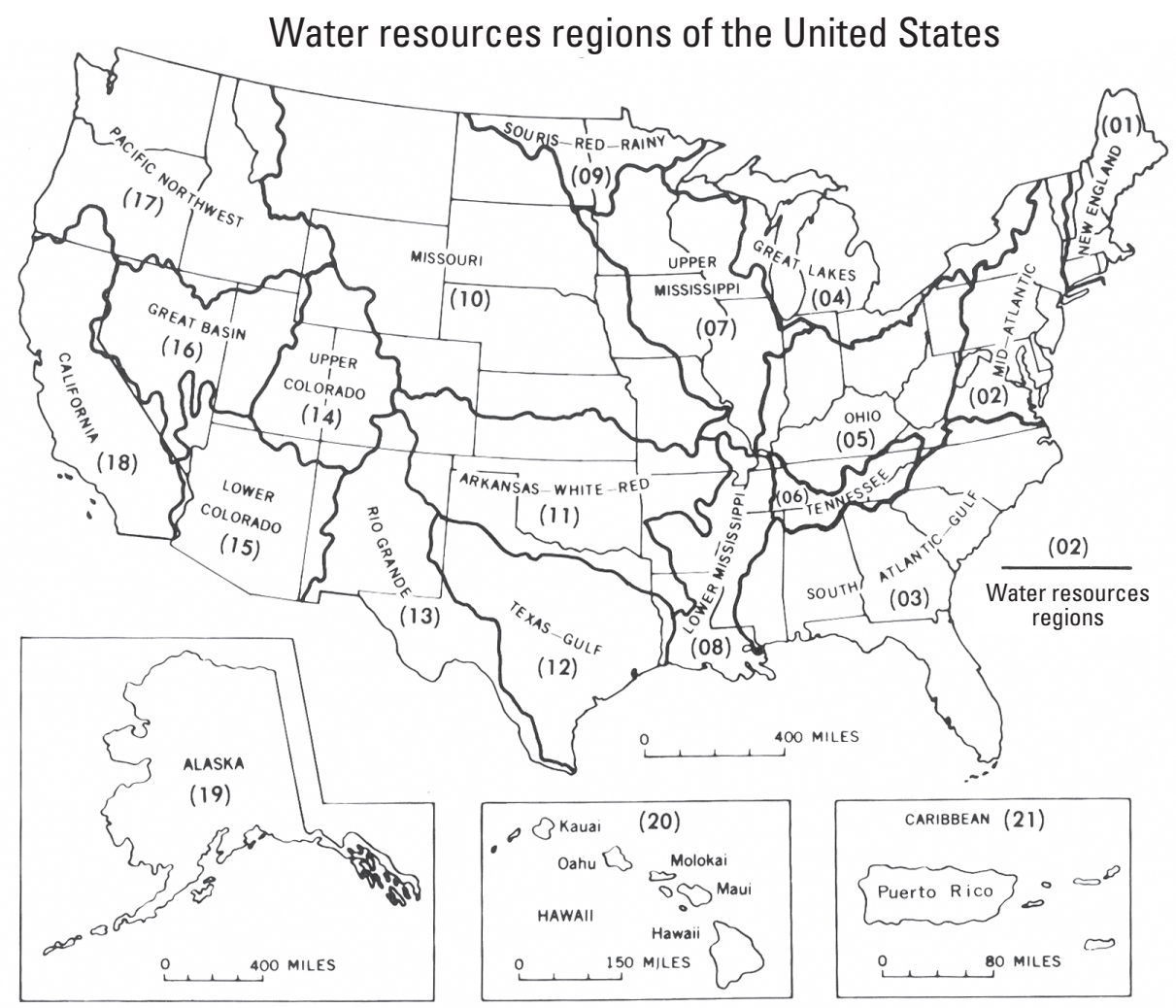

The United States (including Puerto Rico) is divided into 21 large drainages, or water resources regions. These hydrologic areas are based on surface topography and contain either the drainage area of a major river, such as the Columbia, the combined drainage areas of a series of rivers, such as the Texas-Gulf region, which includes a number of rivers draining into the Gulf of Mexico, or the area of an island or island group. Water resources regions provide a coherent, watershed-based framework for depicting streamflow variations.

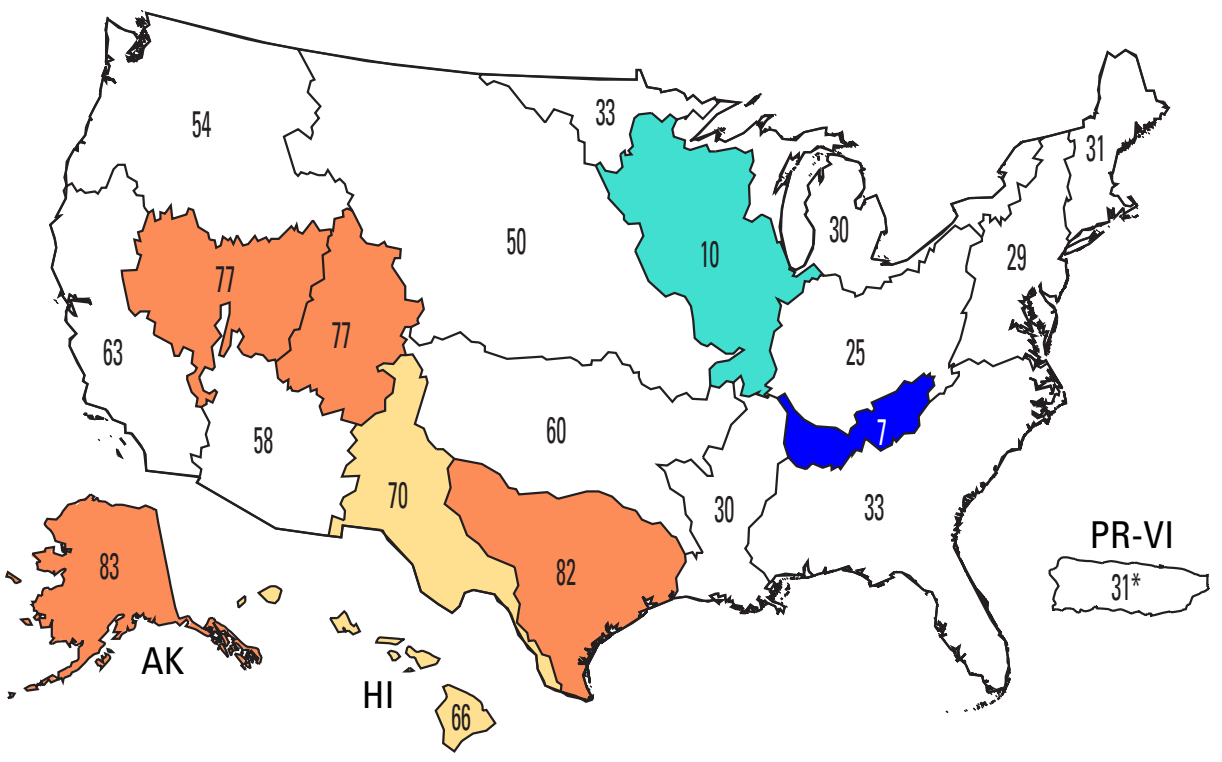

Streamflows at much-below-normal levels were reported in the Alaska, Texas Gulf, Great Basin, and Upper Colorado regions. Below-normal conditions were measured in the Rio Grande and Hawaii regions. Much-above-normal streamflow was reported in the Tennessee region. Above-normal streamflow occurred in the Upper Mississippi region.

\begin{tabular}{|c|c|c|c|c|c|c|}
\hline \multicolumn{7}{|c|}{ Explanation - Rank } \\
\hline 84 & $77-83$ & $64-76$ & $22-63$ & $9-21$ & $2-8$ & 1 \\
\hline \multirow{2}{*}{ Lowest } & $\begin{array}{c}\text { Much } \\
\text { below } \\
\text { normal }\end{array}$ & $\begin{array}{c}\text { Below } \\
\text { normal }\end{array}$ & Normal & $\begin{array}{c}\text { Above } \\
\text { normal }\end{array}$ & $\begin{array}{c}\text { Much } \\
\text { above } \\
\text { normal }\end{array}$ & Highest \\
\hline
\end{tabular}




\section{Seasonal Characteristics}
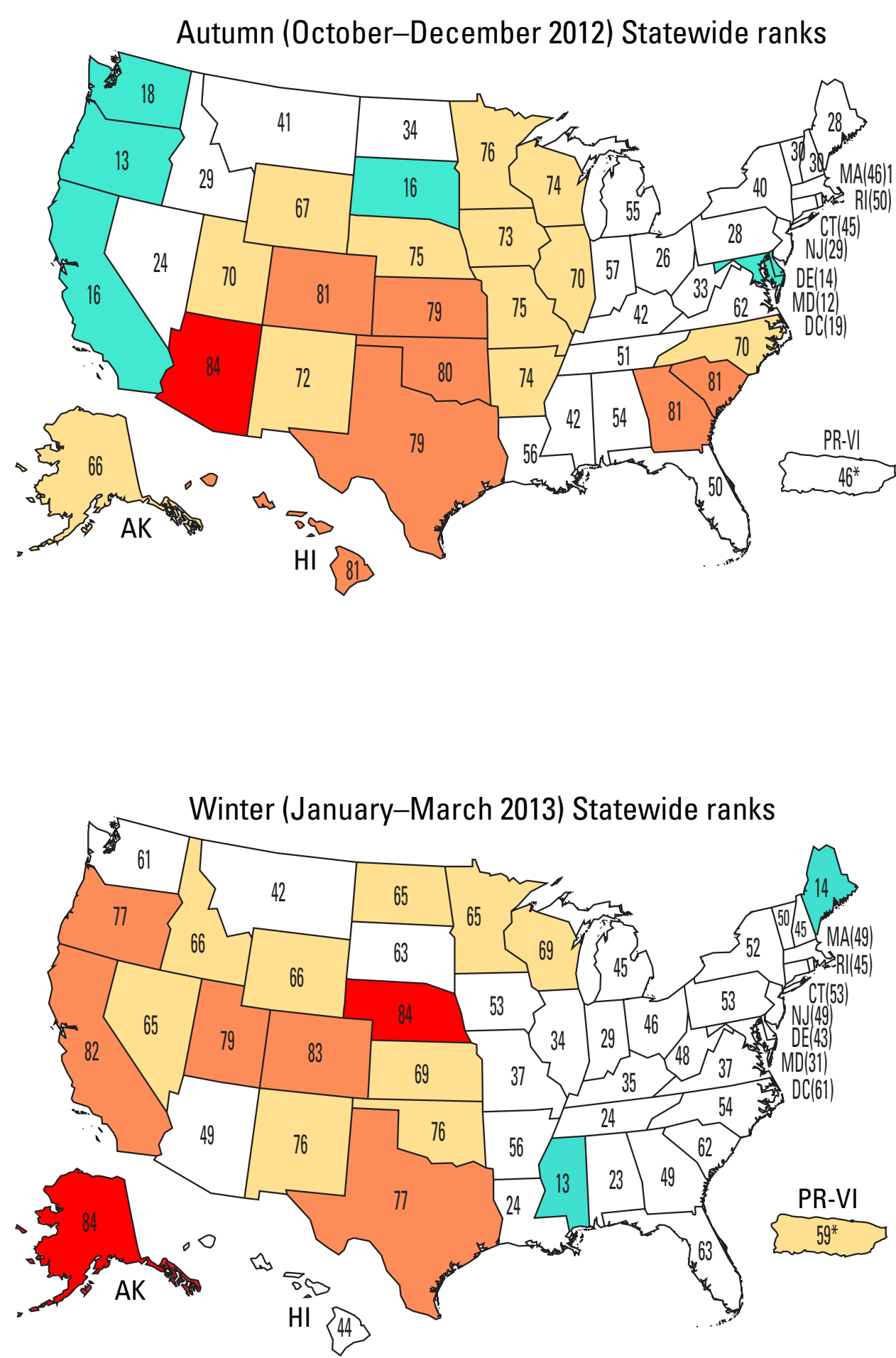

Explanation - Rank

\begin{tabular}{|c|c|c|c|c|c|c|}
\hline 84 & $77-83$ & $64-76$ & $22-63$ & $9-21$ & $2-8$ & 1 \\
\hline Lowest & $\begin{array}{c}\text { Much } \\
\text { below } \\
\text { normal }\end{array}$ & $\begin{array}{c}\text { Below } \\
\text { normal }\end{array}$ & Normal & $\begin{array}{c}\text { Above } \\
\text { normal }\end{array}$ & $\begin{array}{c}\text { Much } \\
\text { above } \\
\text { normal }\end{array}$ & Highest \\
\hline
\end{tabular}

Autumn-season (October-

December) streamflow was at record-low levels (ranking 84th in 84 years) in Arizona. Much-belownormal and below-normal flows were reported in the central, southwestern, and southeastern States: Georgia, South Carolina, Colorado, Oklahoma, Texas, Kansas, Minnesota, Nebraska, Missouri, Arkansas, Wisconsin, Iowa, New Mexico, Utah, Illinois, North Carolina, and Wyoming. Hawaii and Alaska also were at much-below-normal and below-normal levels. Above-normal flows were reported in Washington, Oregon, California, South Dakota, Delaware, and Maryland. Nationwide, autumn-season streamflow ranked 55 th out of 84 years.

* For Puerto Rico, 70 years of available data were used.

Winter-season (January-March) streamflow was at record-low levels in Nebraska and Alaska. Muchbelow-normal and below-normal flows were reported in California, Oregon, Idaho, Nevada, Utah, Wyoming, Colorado, New Mexico, Texas, Oklahoma, Missouri, North Dakota, Minnesota, Wisconsin, and Puerto Rico. Above-normal streamflow was only reported in Mississippi and Maine. Nationwide, winter-season streamflow ranked 66 th out of 84 years.

\section{* For Puerto Rico, 70 years of} available data were used. 


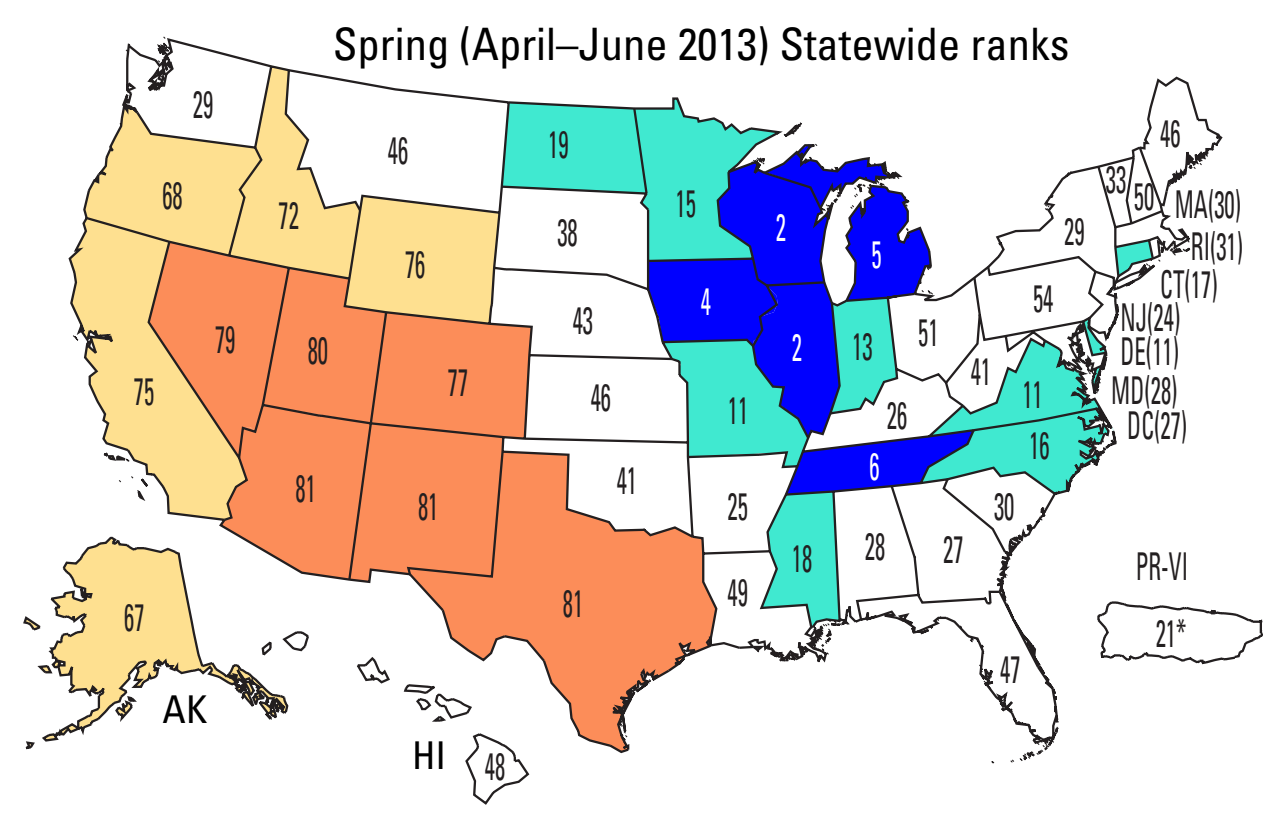

Spring-season (April-June) streamflow was below or much below normal in Texas, New Mexico, Arizona, Colorado, Utah, Nevada, California, Oregon, Idaho, Wyoming, and Alaska. Above-normal and muchabove-normal streamflow was seen in central northern and some east coast States: North Dakota, Minnesota, Wisconsin, Michigan, Iowa, Illinois, Indiana, Missouri, Tennessee, Mississippi, North Carolina, Virginia, Delaware, and Connecticut. Nationwide, spring-season streamflow ranked $33 \mathrm{~d}$ out of 84 years.

* For Puerto Rico, 70 years of available data were used.

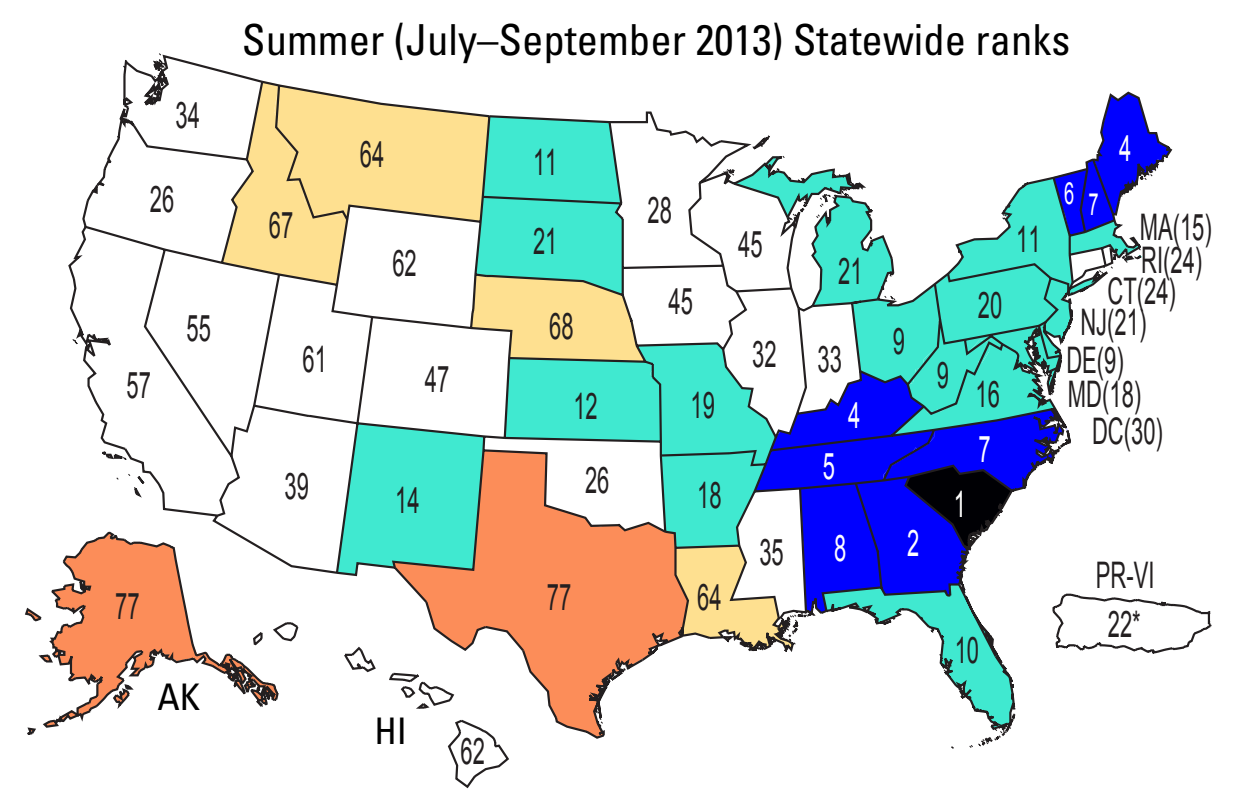

\begin{tabular}{|c|c|c|c|c|c|c|}
\hline \multicolumn{7}{|c|}{ Explanation - Rank } \\
\hline 84 & $77-83$ & $64-76$ & $22-63$ & $9-21$ & $2-8$ & 1 \\
\hline Lowest & $\begin{array}{c}\text { Much } \\
\text { below } \\
\text { normal }\end{array}$ & $\begin{array}{c}\text { Below } \\
\text { normal }\end{array}$ & Normal & $\begin{array}{c}\text { Above } \\
\text { normal }\end{array}$ & $\begin{array}{c}\text { Much } \\
\text { above } \\
\text { normal }\end{array}$ & Highest \\
\hline
\end{tabular}

Summer-season (July-September) streamflow in eastern and southeastern States, as well as a few middle western states, was above or much above normal. South Carolina was at record-high level. Streamflow was below or much below normal in Montana, Idaho, Nebraska, Texas, Louisiana, and Alaska. Nationwide, summer-season streamflow ranked 8 th out of 84 years.

* For Puerto Rico, 70 years of available data were used. 


\section{High and Low Flows}

Percentage of streamgages with very high and very low monthly streamflow October 1999-September 2013

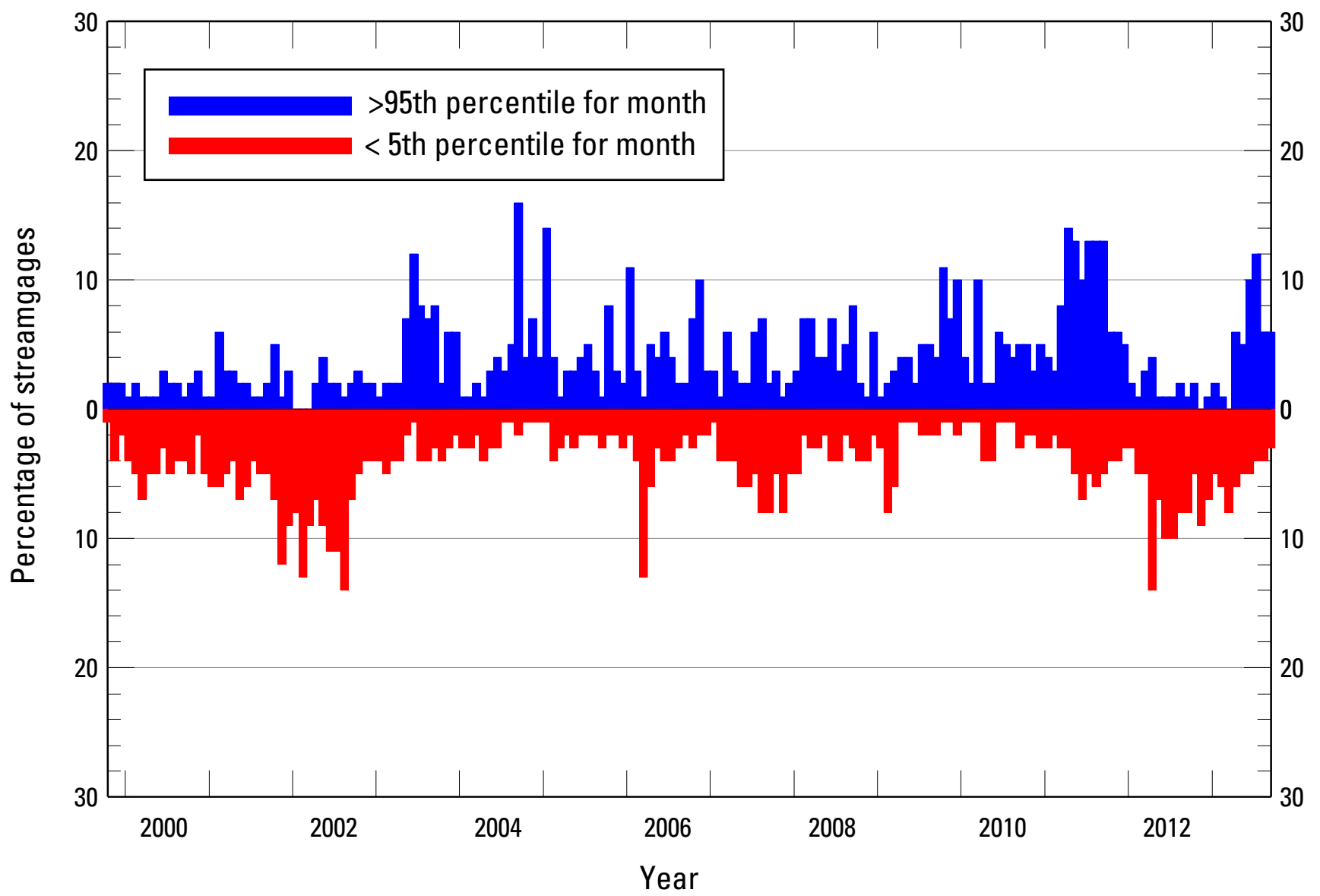

In any given month, on average, it is expected that 5 percent of the streamgages will experience very high $(>95$ th percentile) and very low ( $<5$ th percentile) average streamflow. During water year 2013, 5 spring and summer months (April, June, July, August, and September) had a greater-than-expected percentage of streamgages reporting very high streamflow $(6,10,12,6$, and 6 percent, respectively). In contrast, there were 5 months (from November to April, except January) with a greater-than-expected percentage of streamgages with very low flows $(9,7,6,8$, and 6 percent, respectively). 
Percent of streamgages above bankfull streamflow 1950-2013

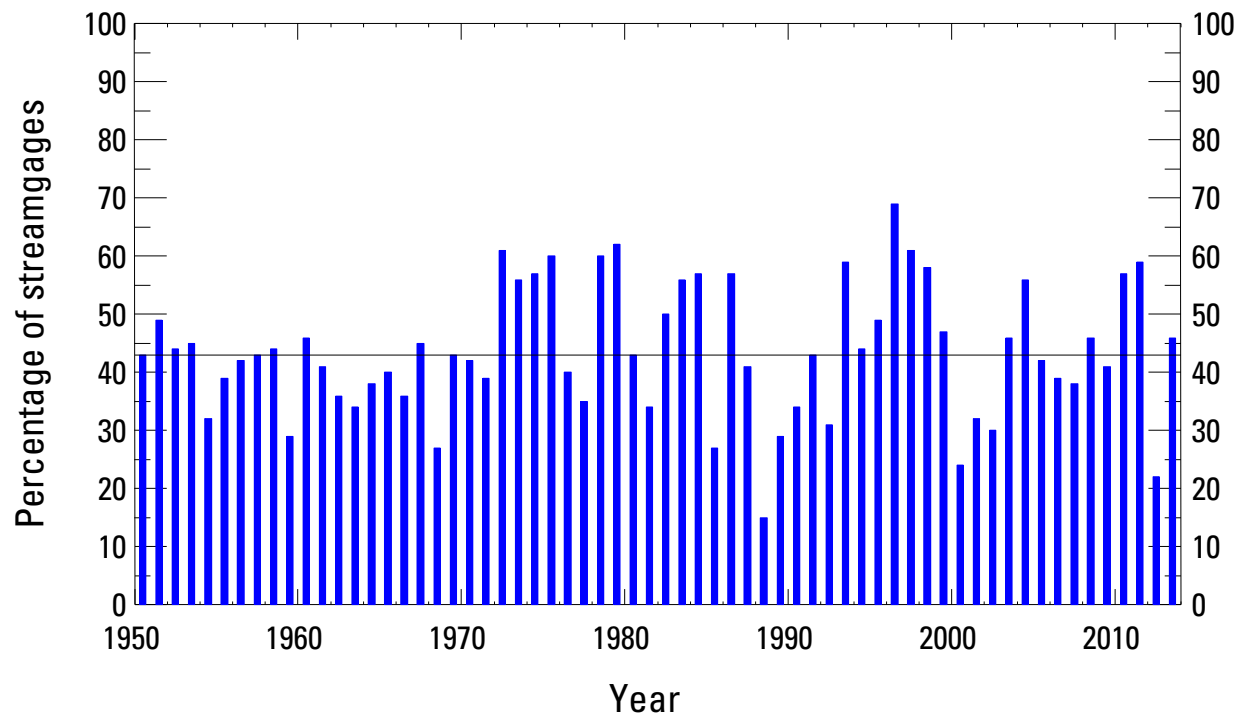

Percent of streamgages below 10th percentile of annual 7-day-minimum streamflow

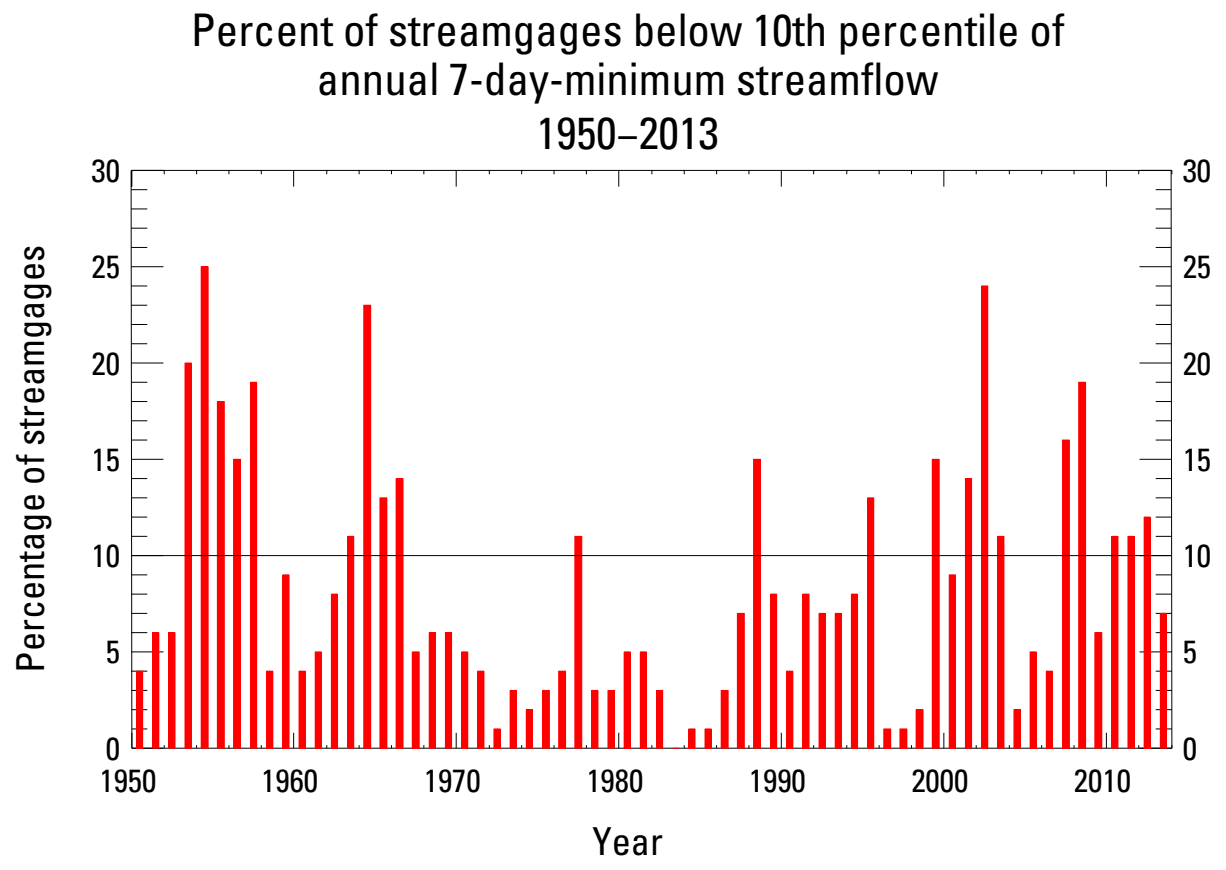

The bankfull streamflow is defined as the highest daily mean streamflow value expected to occur, on average, once in every 2.3 years. In 2013, 46 percent of streamgages had a daily mean streamflow value above the bankfull level. This value is slightly higher than the expected number (43 percent) to occur in any given year. Since 1950, the largest number of streamgages reporting higher-than-bankfull streamflow in any single year was 69 percent, which occurred in 1996.
The 10th percentile 7-day low flow is defined as the lowest 7-dayaverage streamflow expected to occur once every 10 years. In water year 2013, 7 percent of the streamgages reported a 7-day lowflow less than the 10th percentile 7-day low-flow value. The expected number to occur in any given year is 10 percent. Since 1950, the largest percentage of streamgages reporting a 7-day low flow less than the 10 th percentile 7-day low flow was 25 percent, which occurred in 1954. 


\section{Additional Information}

The USGS operates a network of nearly 8,000 streamgages nationwide, most in real time. Current information derived from these

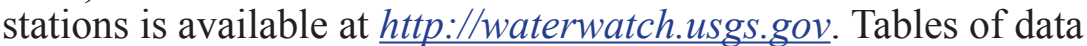
that summarize historical streamflow conditions by State, beginning in 1900 , can be accessed at

http://waterwatch.usgs.gov/?m=statesum. These tables are updated every few months to reflect the most current streamflow data.

The streamflow information used to prepare this summary is also used for water management, monitoring floods and droughts, bridge design, and for many recreational activities. To obtain real-time and archived streamflow data and information, visit http://water.usgs.gov/nwis. Although the national streamgage network is operated primarily by the USGS, it is funded by a partnership of 850 agencies at the Federal, State, tribal, and local levels, and the USGS National Streamflow Information Program (http://water.usgs.gov/nsip/) and the USGS Cooperative Water Program (https://water.usgs.gov/coop/about/monitors.html).
By Xiaodong Jian, David M. Wolock, Harry F. Lins, and Steve Brady

For additional information, contact:

Office of Surface Water

U.S. Geological Survey

415 National Center

Reston, VA 20192

http://water.usgs.gov/osw/

\section{Accessibility FOIA Privacy Policies and Notices}

U.S. Department of the Interior | U.S. Geological Survey

URL: http://waterwatch.usgs.gov

Page Contact Information: Office of Surface Water 